\title{
FREE AMINO ACIDS IN THE VAS DEFERENS, SEMEN, TRANSPARENT FLUID AND BLOOD PLASMA OF THE DOMESTIC ROOSTER, GALLUS DOMESTICUS
}

\author{
P. E. LAKE AND M. HATTON \\ A.R.C. Poultry Research Centre, King's Buildings, Edinburgh, and \\ Twyford Laboratories Ltd, Twyford Abbey Road, London
}

(Received 19th Fune 1967, revised 4th August 1967)

Semen of the domestic rooster may contain contents of the vasa deferentia with no, or very variable amounts of, 'transparent fluid' from structures in the cloaca, depending upon the way in which it is collected by massage (Lake, 1966). The significance of transparent fluid as a component of seminal plasma is not fully understood (Lake, 1966) and thus an examination of all the possible fluid portions of semen, which can be obtained by massage, is important in determining their origin and significance in the reproductive physiology of the fowl. The presence of transparent fluid is detrimental to the prolonged survival of spermatozoa in vitro (see Lake, 1966).

Lake \& McIndoe (1959), using paper chromatography, found a large amount of free glutamic acid in the seminal plasma of the fowl which was free from transparent fluid. Later Goldberg, Pence \& Norman (1961), Chubb \& Cooper (1962), Yoshida \& Masuda (1962) and Ahluwalia \& Graham (1966) showed that this was the most dominant amino acid in fowl semen which may have contained transparent fluid.

The present communication deals with a comparison of the free amino acids found in: (a) semen which was collected without contamination by transparent fluid, (b) transparent fluid, and (c) blood plasma.

Semen, free of transparent fluid, was collected on several different occasions by massage (Lake, 1957) and, each time, pooled from twelve Brown Leghorn roosters (Breeding line males; see Blyth, 1954) which were fed on a breeders' mash (El Jack \& Lake, 1966). Within 15 min of collection the semen was centrifuged $\left(3200 \mathrm{~g} ; 30 \mathrm{~min} ; 5^{\circ} \mathrm{C}\right.$ ) and the spermatozoa separated immediately. Another rooster, which had ligatures placed between the epididymides and vasa deferentia, was massaged several times, in a similar manner for semen collection, until the contents of the vasa were aspermic. Later, several samples of the opaque vasa secretion were collected, stored at $-20^{\circ} \mathrm{C}$ and pooled until sufficient fluid was available for analysis. In addition to this sample of secretion, other samples were obtained by centrifuging the contents of the vasa deferentia taken from two freshly-killed birds. Transparent fluid was obtained from the male with ligatures in its reproductive tract by squeezing the fluid from the erected lymph folds after the initial forceful ejaculation of the contents of the vasa deferentia had been collected. Samples of blood were collected with a 
heparinized syringe from the wing veins of four of the males and were centrifuged immediately in the cold to remove the cells.

The various fluids were deproteinized with 10 volumes of $1 \%$ picric acid at $5^{\circ} \mathrm{C}$. The precipitate was removed by centrifugation at $5^{\circ} \mathrm{C}$ and the picric acid removed from the supernatant by passing it through a column of Deacidite FF in the chloride form. The resin bed was washed with 5 volumes of 0.01 $\mathrm{N}-\mathrm{HCl}$ and the effluent collected and concentrated at $40^{\circ} \mathrm{C}$. The concentrate was washed several times with distilled water, dried and quantitatively transferred to a small tube using $0.2 \mathrm{M}$-sodium citrate buffer at $\mathrm{pH} 2 \cdot 2$. Aliquots

TABLE 1

COMPARISON OF THE CONTENT ( $\mathrm{mg} / 100 \mathrm{ml}$ ) OF SOME FREE AMINO ACIDS IN BLOOD PLASMA, SEGRETIONS OF THE VAS DEFERENS, EJAGULATED SEMINAL PLASMA UNCONTAMINATED WITH TRANSPARENT FLUID, AND TRANSPARENT FLUID OF THE DOMESTIC ROOSTER

\begin{tabular}{|c|c|c|c|c|c|}
\hline Amino acid & $\begin{array}{c}\text { Blood } \\
\text { plasma }\end{array}$ & $\begin{array}{l}\text { Transparent } \\
\quad \text { fluid }\end{array}$ & $\begin{array}{r}F l \\
\text { vas } \\
(1)^{*}\end{array}$ & $\begin{array}{l}\text { from } \\
\text { ferens } \\
\qquad(2) \dagger\end{array}$ & $\begin{array}{l}\text { Seminal plasma } \\
\text { uncontaminated with } \\
\text { transparent fuid }\end{array}$ \\
\hline $\begin{array}{l}\text { Cysteic acid } \\
\text { Taurine } \\
\text { Methionine Sulphone } \\
\text { Aspartic acid } \\
\text { Threonine } \\
\text { Serine } \\
\text { Glutamic acid } \\
\text { Proline } \\
\text { Glycine } \\
\text { Alanine } \\
\text { Cysteine } \\
\text { Valine } \\
\text { Methionine } \\
\text { Isoleucine } \\
\text { Leucine } \\
\text { Tyrosine } \\
\text { Phenylalanine } \\
\text { Lysine } \\
\text { Histidine } \\
\text { Ornithine } \\
\text { Urea } \\
\text { Arginine } \\
\text { Ammonia }\end{array}$ & $\begin{array}{c}2 \cdot 4 \\
4 \cdot 7 \\
\text { Trace } \\
1 \cdot 1 \\
4 \cdot 1 \\
3 \cdot 3 \\
3 \cdot 3 \\
4 \cdot 5 \\
3 \cdot 3 \\
2 \cdot 7 \\
0 \cdot 8 \\
4 \cdot 1 \\
\text { Trace } \\
2 \cdot 0 \\
3 \cdot 2 \\
2 \cdot 2 \\
1 \cdot 0 \\
8 \cdot 0 \\
1 \cdot 7 \\
\text { Trace } \\
\text { Trace } \\
5 \cdot 0 \\
7 \cdot 3\end{array}$ & $\begin{array}{c}\text { Trace } \\
4 \cdot 2 \\
\text { Trace } \\
2 \cdot 0 \\
3.5 \\
2 \cdot 4 \\
4 \cdot 6 \\
4.9 \\
3.0 \\
1.9 \\
- \\
5 \cdot 3 \\
- \\
1.4 \\
2 \cdot 5 \\
\text { Trace } \\
\text { Trace } \\
3.0 \\
\text { Trace } \\
- \\
\text { Trace } \\
1.7 \\
4.6\end{array}$ & $\begin{array}{c}\text { Trace } \\
5 \cdot 5 \\
- \\
6 \cdot 3 \\
\text { Trace } \\
\text { Trace } \\
801 \cdot 0 \\
- \\
1 \cdot 3 \\
1 \cdot 3 \\
- \\
- \\
- \\
= \\
- \\
- \\
\text { Trace } \\
- \\
- \\
- \\
\text { Trace } \\
7 \cdot 3\end{array}$ & $\begin{array}{c}- \\
5 \cdot 9 \\
- \\
11 \cdot 4 \\
\text { Trace } \\
\text { Trace } \\
1461 \cdot 0 \\
- \\
4 \cdot 4 \\
\text { Trace } \\
- \\
- \\
- \\
\text { Trace } \\
\text { Trace } \\
- \\
- \\
- \\
- \\
- \\
- \\
- \\
6.3\end{array}$ & $\begin{array}{c}? \\
5 \\
- \\
20 \cdot 3 \\
3 \cdot 2 \\
5 \cdot 0 \\
1300 \\
- \\
4 \cdot 0 \\
3 \cdot 3 \\
\text { Trace } \\
1 \cdot 5 \\
\text { Trace } \\
\text { Trace } \\
\text { Trace } \\
- \\
- \\
1 \cdot 5 \\
- \\
\bar{?} \\
- \\
\text { Variable (see text) }\end{array}$ \\
\hline
\end{tabular}

* Sperm-free fluid.

$\uparrow$ Vas contents centrifuged immediately after extraction from two freshly-killed males.

of this solution were applied on each of two Amberlite CG120 columns of an amino acid analyser (Evans Electroselenium Ltd) according to the method of Spackman, Stein \& Moore (1958). The first $150 \mathrm{~cm}$ column was eluted with $0.2 \mathrm{M}$-sodium citrate buffer, $\mathrm{pH} 3.23\left(50^{\circ} \mathrm{C}\right)$ followed by $\mathrm{pH} 4.25$. The second $15 \mathrm{~cm}$ column was eluted with $0.35 \mathrm{M}$-sodium citrate buffer at $\mathrm{pH}$ $5 \cdot 28\left(50^{\circ} \mathrm{C}\right)$.

The results shown in Table 1 confirm that glutamic acid is the predominant free amino acid in fowl seminal plasma. The direct analyses of samples of seminal plasma, ejaculated free from transparent fluid, and of fluid from the vas deferens were difficult owing to the large amount of glutamic acid present. Extracts equivalent to about $0.005 \mathrm{ml}$ of original fluid were analysed to obtain 
the most reliable estimate of the amount of glutamic acid. Larger amounts were analysed for the other amino acids, in which cases the form of the curve representing glutamic acid on the chart was large and sometimes skew and could not be used for its quantification. Due consideration had always to be given to the possibility of interference by the glutamic acid when quantifying the amino acids present in small amounts. Aspartic acid was the next most prominent free amino acid in seminal plasma uncontaminated with transparent fluid, followed by taurine, threonine, serine, glycine and alanine. Valine and lysine were present in minute quantities and only traces of cysteine, methionine, isoleucine and leucine occurred. A small quantity of ammonia $(5 \mathrm{mg} / 100 \mathrm{ml}$ ) was detected when extracts were analysed soon after preparation. However, in two samples that were held in the refrigerator for several weeks before analysis the amount of ammonia found was 25 and $24 \mathrm{mg} / 100 \mathrm{ml}$, respectively, and may have been due to the breakdown of amino acids during storage. A small quantity of cysteic acid was detected in one sample of seminal plasma only, but further work is necessary to substantiate its presence, because it was eluted at the column front. Lake \& MacIndoe (1959) and Chubb \& Cooper (1962) reported the detection of cysteic acid by paper chromatography.

Chubb \& Cooper (1962) and Ahluwalia \& Graham (1966) reported asparagine in the semen of the fowl and Chubb \& Cooper (1962) detected proline. These compounds were absent in the seminal plasma without transparent fluid, but proline was found in blood plasma and transparent fluid. The semen collected by these authors may have contained transparent fluid. However, it is difficult to explain our differences concerning asparagine since the latter was reported to be present in large amount $(1 \mathrm{mg} / 100 \mathrm{ml})$ by Ahluwalia \& Graham (1966). Asparagine and serine are eluted close together and it may be possible to confuse their identification. Picric acid was used for de-proteinization in both studies and thus it is considered unlikely that the deamination of asparagine occurred extensively in the present work.

Ahluwalia \& Graham (1966) reported large amounts of urea, threonine, arginine, methionine and tyrosine and a small quantity of histidine in the seminal plasma. None of these were positively identified in our studies although a small, unidentifiable peak occurred on the chart immediately following taurine, which was initially thought to be urea. These discrepancies between the two investigations are inexplicable. However, urinary and/or faecal contamination of the semen collected by massage could lead to an increased number of nitrogenous compounds being found, and the amount of transparent fluid in semen could influence the findings regarding the presence of free amino acids. Also, the quantity of amino acids in blood plasma (and thus transparent fluid from which it is derived) may vary with the composition of the diet. Lewis (1967) has recently discussed the variation found in the amino acid composition of the plasma with different dietary levels of amino acids.

The blood plasma of the rooster contained a wide variety of amino acids in small amounts and, except for arginine, lysine, tyrosine and cysteic acid, closely resembled the composition of transparent fluid. The latter is largely a dialysate of blood plasma (see Lake, 1966) and is likely to be contaminated with secretions from glandular cells in the cloaca. 
The origin of the large amount of free glutamic acid in the semen of the fowl has not yet been established. Lake \& McIndoe (1959) suggested that it originated mainly in the testis. The reduced amount of glutamic acid in the vas fluid of the rooster, which had a ligature at each junction of the epididymis and vas deferens, would tend to support this view. It is not certain whether any glutamic acid was produced by cells of the vas deferens because, although the fluid was aspermic, some products from the seminiferous tubules may still have been present at the time of collection. Hammond, Boone \& Barnett (1965) demonstrated glutamic oxaloacetic transaminase and glutamic pyruvic transaminase activities in seminal plasma of the rooster which could give rise to glutamic acid in the reproductive tract.

It is not known whether glutamic acid plays a more specific or active part in the life of the formed fowl spermatozoa than that of maintenance of $\mathrm{pH}$ and osmotic pressure. However, El Zayat \& Van Tienhoven $(1960,1961$ a) showed that the spermatozoa of the rooster, under certain circumstances, may catabolize glutamic acid in vitro with the production of carbon dioxide. Also the amino acid prevented the deterioration of the structure of the spermatozoon (El Zayat \& Van Tienhoven, 1961b). Lake (1960) and Van Wambeke (1967) obtained encouraging results using diluents containing glutamate for storing fowl semen in vitro.

A possibility, which has yet to be investigated, is that glutamic acid is formed as a result of the synthetic and catabolic processes occurring during rapid cell division (spermatogenesis) in the seminiferous tubules. Much of it may be 'excreted' through the vasa deferentia.

The advice and interest shown in this work by Dr Leggatt Bailey are gratefully acknowledged. We are indebted to the Director of the Twyford Laboratories for laboratory facilities. We also wish to thank Dr J. J. Waring, of the Poultry Research Gentre, for carrying out a few analyses with the Technicon Automatic Amino Acid Analyser verifying the identification of some amino acids, and Mr J. Stewart for technical assistance.

\section{REFERENCES}

Ahluwalla, B. S. \& Graham, E. F. (1966) Free amino acids in the semen of the fowl and the turkey. 7. Reprod. Fert. 12, 365.

Blyth, J. S. S. (1954) Notes on the Poultry Research Centre flock of Brown Leghorns. Wld's Poult. Sci. F. 10, 140.

Chubb, L. G. \& Cooper, D. M. (1962) Amino acids in fowl seminal plasma. F. Reprod. Fert. 4, 7.

EL JACK, M. H. \& LAKE, P. E. (1966) The distribution of the principal inorganic ions in venous blood of the adult domestic cock and the content of carbon dioxide in the plasma. Br. Poult. Sci. 7, 315.

El Zayat, S. \& VAN Tienhoven, A. (1960) The effect of glutamate on rooster sperm metabolism and morphology. Poult. Sci. 39, 1247.

El Zayat, S. \& VAN TiEnhoven, A. (1961a) Effect of glutamate and glycine on cock sperm metabolism. Proc. Soc. exp. Biol. Med. 106, 803.

El Zayat, S. \& Van Tienhoven, A. (1961b) Effect of chloride ions on cock spermatozoa. Am. $\mathcal{J}$. Physiol. 200, 819.

Goldberg, E., Pence, V. W. \& Norman, C. (1961) The distribution of free amino acids in cock and bull seminal plasma and spermatozoa (Abstract). Am. Zool. 1, 356.

Hammond, M., Boone, M. A. \& Barnett, D. B. (1965) Study of the glucose, electrolytes, enzymes and nitrogen components of fowl seminal plasma. F. Reprod. Fert. 10, 21. 
LAKE, P. E. (1957) Fowl semen as collected by the massage method. F. agric. Sci. 49, 120.

LAKE, P. E. (1960) Studies on the dilution and storage of fowl semen. F. Reprod. Fert. 1, 30.

LAKe, P. E. (1966) Physiology and biochemistry of poultry semen. In: Advances in Reproductive Physiology. Vol. I, pp. 93-123. Ed. A. McLaren. Logos Press, London.

Lake, P. E. \& MaIndoe, W. M. (1959) The glutamic acid and creatine content of cock seminal plasma. Biochem. F. 71, 303.

Lewrs, D. (1967) Plasma amino acid levels. In: Protein Utilization by Poultry, pp. 57-63. B.E.M.B. Symposium No. 2. Eds. R. A. Morton and E. C. Amoroso. Oliver \& Boyd, Edinburgh.

Spackman, D. H., Stein, W. H. \& Moore, S. (1958) Automatic recording apparatus for use in the chromatography of amino acids. Analyt. Chem. 30, 1190.

Van Wambeke, F. (1967) The storage of fowl spermatozoa. I. Preliminary results with new diluents. 7. Reprod. Fert. 13, 571.

Yoshma, S. \& MAsuda, H. (1962) Studies on the composition and metabolism of fowl semen. Zootec. Vet. 17, 528. 